\title{
OPTIMIZATION OF SWEET GUAVA (Psidium guajava, L) USING THE ACCEPTANCE TEST, RESPONSE SURFACE METHODOLOGY AND PREFERENCE MAP
}

\author{
CAMILA CARVALHO MENEZES* \\ SORAIA VILELA BORGES** \\ JOÃO DE DEUS SOUZA CARNEIRO*** \\ MARCELO ANGELO CIRILLO**** \\ ANA CARLA MARQUES PINHEIRO*****

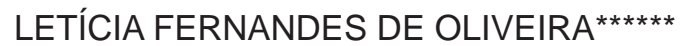

\begin{abstract}
This study aimed to evaluate the influence of the independent variables concentration of citric acid, concentration of potassium sorbate, and pulp/sugar ratio on consumer acceptance for sweet guava. The results were analyzed using statistical methods such as preference map and response surface methodology to determine the influence of the independent variables. Response surface methodology alone proved insufficient to achieve an optimal formulation for the preparation of sweet guava. Based on preference mapping analysis, consumer preference was observed for treatments using higher concentrations of sugar and citric acid. Parameters of sweetness, appearance and texture influenced consumer preferences.
\end{abstract}

* Nutricionista, Doutora em Ciência dos Alimentos, Professora Adjunto, curso de Bacharelado em Nutrição, Universidade Federal do Piauí, Picos, PI (e-mail: camilacarvalhomenezes@yahoo.com.br).

** Engenheira Química, PhD em Polímeros, Instituto de Macromoléculas Heloísa Mano, RJ, Professora Associada, Departamento de Ciência dos Alimentos, Universidade Federal de Lavras (UFL), Lavras, MG (e-mail: sborges@dca.ufla.br).

*** Engenheiro de Alimentos, Doutor em Ciência e Tecnologia de Alimentos, Professor Adjunto, Departamento de Ciência dos Alimentos, UFL, Lavras, MG (e-mail: joaodedeus@dca.ufla.br).

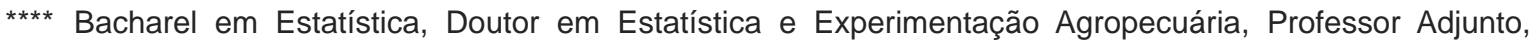
Departamento de Ciências Exatas, UFL, Lavras, MG (e-mail: marcelocirillo@hotmail.com).

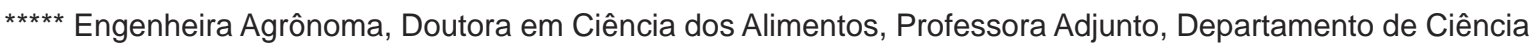
dos Alimentos, UFL, Lavras, MG (e-mail: anacarlamp@dca.ufla.br).

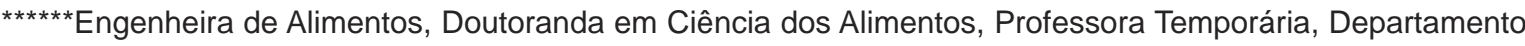
de Ciência dos Alimentos, UFL, Lavras, MG (e-mail: letferol@yahoo.com.br). 


\section{INTRODUCTION}

The fruit and its derivatives are products of interest in world trade, representing an important source of income for many developing countries (BRITO et al., 2011). Brazil is one of the richest countries in tropical fruits, among them guava (Psidium guajava L.), a flavored and perfumed fruit (BRITO et al., 2009).

According to Mori, Yotsuanagi e Ferreira (1998) sweet guava, should have a characteristic color ranging from yellowish-red to brownish-red, a characteristic smell and taste of guava, and a jellylike yet solid texture that allows the preserve to be sliced. However, the large majorities of companies producing this type of food are small or medium-sized, and therefore lack quality control procedures. Absence of quality control standards can be a major drawback for product expansion to new markets.

The determination of consumer acceptance is a crucial part of product development and quality improvement (STONE \& SIDEL, 2004; ABDULLAH \& CHENG, 2001; MENDES et al. 2001). Modern food industries have been using consumer sensory analysis to develop new products or to optimize existing processes (HOWARD, HUNG \& MCWATTERS, 2011; LEE et al., 2011; KUMAR, RAVI \& SARASWATHI, 2010; CHANG et al., 1998).

In sensory analysis, response surface methodology (BOX \& DRAPER, 2007) is used as a model consumer response (ROYER et al., 2006). The model generates predictive equations that correlate the consumer response and the process. These predictive equations (models) may be used to optimize processing and to estimate the expected consumer response to a combination of factors that are not directly tested (MOSKOWITZ, 1994).

Acceptance data are usually analyzed by statistical techniques that consider univariate responses. This assumes that consumer acceptability is homogenous, and therefore the values obtained may fail to reflect their actual mean. However, individual data variability should also be taken into account (CARDELLO \& FARIA, 2000). An alternative is to use a statistical technique known as preference mapping, consisting of a set of statistical procedures based on principal component analysis (PCA), cluster analysis, and multiple polynomial regression (SCHLICH, 1995).

The objective of this work was to evaluate the influences of the concentration of citric acid, concentration of potassium sorbate, and pulp/sugar ratio on the acceptance of sweet guava by consumers using an acceptance test, response surface methodology and preference map.

\section{MATERIAL AND METHODS}

\subsection{EXPERIMENTAL DESIGN}

A full $2^{3}$ factorial design with notations \pm 1 and three replications at the center point (level 0 ) was used as described by Box \& Draper (2007). The pulp/sugar ratio and the concentrations of citric acid and potassium sorbate in the pulp were defined as independent variables. The variations in the concentrations of the independent variables were defined according to data in the literature (TORREZAN, 2003), and to limits established by Brazilian legislation (BRASIL, 1978) regarding the addition of sorbic acid and its salts to the sweet guava (Table 1).

TABLE 1 - INDEPENDENT VARIABLES AND VARIATION LEVELS

\begin{tabular}{lccc}
\hline \multirow{2}{*}{ Independent variables } & \multicolumn{3}{c}{ Variation levels } \\
\cline { 2 - 4 } & $\mathbf{- 1}$ & $\mathbf{0}$ & $\mathbf{+ 1}$ \\
\hline Citric acid (\%) & 0.00 & 0.25 & 0.50 \\
Potassium sorbate (\%) & 0.00 & 0.05 & 0.10 \\
Pulp/sugar (g/g) & $50 / 50$ & $55 / 45$ & $60 / 40$ \\
\hline
\end{tabular}




\subsection{SWEET GUAVA PROCESSING}

Guavas of the Pedro Sato cultivar at an advanced ripening stage were provided by the Lavras Association of Fruit Producers (FRUTILAVRAS) in the crop year 2007. They were stored at $\pm 5^{\circ} \mathrm{C}$ until they were processed. The ingredients used were crystal sugar (commercial), citric acid monohydrate (commercial grade NUCLEAR), high methoxylation citrus pectin (commercial grade VETEC) and potassium sorbate (commercial grade VETEC).

The fruit was rinsed under running water and sanitized in a sodium hypochlorite solution at $200 \mathrm{mg} \mathrm{L}^{-1}$ for 15 minutes, then selected and blanched to inactivate the enzymes responsible for enzymatic darkening and the activity of peroxidase was analyzed according to Matsumo and Uritane (1972). A heat treatment at $100^{\circ} \mathrm{C}$ for 5 minutes was sufficient to fully inactivate this enzyme. Peroxidase is an enzyme in fruits and vegetables with one of the highest thermal stabilities, and it is largely used as an indicator of blanching and other heat-producing processes.

The guava fruits were pulped using an electric depulper ( $0.6 \mathrm{~mm}$ diameter sieve) and the preserve was processed in a lidless stainless steel pot. Pulp and sugar were added first, followed by pectin ( $0.5 \%$ of the pulp in all treatments). Citric acid was added toward the end of the cooking process in order to prevent degradation of the pectin due to acidity and high temperature. Potassium sorbate was dissolved into the pulp (on average, one part sorbate to four parts pulp) and added when the preserve had reached a concentration of approximately $50^{\circ} \mathrm{Brix}$. Each preserve formulation (Table 2) was heated until the preserve reached a soluble solid content of $73^{\circ}$ Brix. While still hot, the preserve was stored in polypropylene containers and left to cool at room temperature.

TABLE 2 - SWEET GUAVA FORMULATIONS

\begin{tabular}{cccccc}
\hline \multirow{2}{*}{ Formulations Ingredients } \\
\cline { 2 - 5 } & Pulp (\%) & Sugar (\%) & Potassium sorbate (\%) & Citric acid (\%) & Pectin(\%) \\
\hline 1 & 60.0 & 40.0 & 0.10 & 0.50 & 0.50 \\
2 & 50.0 & 50.0 & 0.10 & 0.50 & 0.50 \\
3 & 60.0 & 40.0 & 0.00 & 0.50 & 0.50 \\
4 & 50.0 & 50.0 & 0.00 & 0.50 & 0.50 \\
5 & 60.0 & 40.0 & 0.10 & 0.00 & 0.50 \\
6 & 50.0 & 50.0 & 0.10 & 0.00 & 0.50 \\
7 & 55.0 & 45.0 & 0.00 & 0.00 & 0.50 \\
8 & 55.0 & 45.0 & 0.00 & 0.25 & 0.50 \\
9 & 55.0 & 55.0 & 0.05 & 0.50 \\
\hline
\end{tabular}

\subsection{ACCEPTANCE TEST}

Seventy-five people living in Lavras (Minas Gerais State) answered a preliminary questionnaire, and based on the results for sweet guava intake frequency (at least occasional) fiftyfour people were selected to participate in the sensory analysis.

Of the forty-four consumers participating in the acceptance test, $73 \%$ were female, $52 \%$ were aged between 20 and 29 , and $77 \%$ had a family income of 1 to 10 minimum wages. The consumption of sweet guava between men and women was $47 \%$ (women) and $42 \%$ (men) which eat this product occasionally.

The test was conducted in individual cabins and the eleven samples of sweet guava $\left(2^{3}\right.$ factorial +3 center points) were served individually in three sessions. The presentation order of the samples followed the experimental design for treatment evaluation described by Wakeling and Macfie (1995). In this design, each treatment appeared the same number of times in each position and was preceded the same number of times by each of the others. This design avoided both the presentation order effect and the residual effect. The chosen design was comprised of 44 different presentation sequences in order to estimate the main effects without bias.

The consumers were given approximately $30 \mathrm{~g}$ of each sample in disposable plastic cups coded with three-digit numbers. 
The acceptance of the samples was based on the attributes of 'appearance', 'color', 'sweetness', 'guava taste', 'texture' and 'overall impression', using a nine-point hedonic scale that ranged from 'I dislike extremely' (Score 1) to 'I like extremely' (Score 9).

\subsection{STATISTICAL ANALYSIS OF RESULTS}

The data obtained with the preliminary questionnaire were tabulated and submitted to a frequency analysis in order to outline the profile of consumers participating in the sensory analysis.

For each treatment, including the central points, the dependent variables (acceptance scores for sensory attributes) were evaluated and the mean acceptance data were submitted to regression analysis. A first-order regression model containing linear terms and the binary interactions of the three independent variables was adjusted $\left(x_{1}, x_{2}\right.$, and $\left.x_{3}\right)$ to generate the response surface. Analysis of variance (ANOVA) was applied to test the fitness of the models, and the significance of regression analyzed using the $F$ test and the coefficient of determination (BARROS NETO, SCARMINIO \& BRUNS, 1995). The full linear models and the independent variables were used to construct the response surfaces. The statistical analysis was performed using statistics software Statistica 8.0 (STATSOFT, 2008).

To construct the preference map, the mean acceptance score of the three replications at the center point was determined. Each consumer's mean acceptance scores were first analyzed using Principal Component Analysis (PCA) for the parameters of appearance, color, guava taste, sweetness and texture. For PCA, the data were organized into a matrix with the samples arranged in rows and the mean acceptance scores arranged in columns. This method produced a low number of independent components and minimized the loss of original information (variation). The covariance matrix was chosen because the same type of scale was used for each parameter being evaluated. According to methodology of Reis et al. (2006), this avoided the need to standardize the variables.

The preference map was derived by fitting a polynomial regression of the acceptance scores in relation to the overall impression of each consumer individually $\left(Y_{i}, i=1, \ldots, 44\right)$, as a function of variables $\mathrm{X}_{1}$ and $\mathrm{X}_{2}$ (principal components 1 and 2). The model proposed was vectorial, consisting of a multiple linear regression of $Y_{i}$ on $X_{1}$ and $X_{2}$ as illustrated in Equation 1 (SCHLICH, 1995):

$$
Y_{i}=a+b_{1} X_{1_{i}}+b_{2} X_{2_{i}}
$$

$Y_{i}=$ acceptance score of overall impression for the ith consumer; $X_{1 i}=$ score of the 1st principal component for the ith consumer; $\mathrm{X}_{2 i}=$ score of the 2 nd principal component for the $i$ th consumer; $\mathrm{a}=$ intercept; $\mathrm{b}_{k}=$ regression coefficients of the model $(k=1,2)$.

The preference $\left(X_{1} \cdot X_{2}\right)$ for each treatment was provided as a percentage of consumers preferring the treatment $(j)$ with coordinates $X_{1 j}$ and $X_{2 j}$ on the sensory map in relation to the overall impression. Preference was referred to as an index given by Equation 2:

$$
\operatorname{Pr} e f\left(X_{1,}, X_{2,}\right)=100 * \frac{\sum_{j=1}^{n} c_{j}\left(X_{1, j}, X_{2,}\right)}{n}
$$

$X_{1 j}=$ score of the 1 st principal component for the jth treatment; $X_{2 j}=$ score of the $2 n d$ principal component for the jth treatment; $\mathrm{n}=$ number of consumers; $j=$ number of treatments $(1, \ldots, 9)$; $c_{i}=$ coordinate of each treatment $j$ in relation to each individual consumer, coded as follows: $c_{j}\left(X_{1 j} \cdot X_{2 j}\right)=1$, if $f_{i}\left(X_{1 j} \cdot X_{2 j}\right) \geq$ overall mean score; $c_{j}\left(X_{1 j} X_{2 j}\right)=0$, if $f_{i}\left(X_{1 j} X_{2 j}\right)<$ overall mean score.

To facilitate the understanding and discussion of results, a scatter plot of the samples created by principal component analysis was plotted onto the preference map.

A correlation graph was created of the acceptance data relating to the sensory attributes appearance, color, sweetness, guava taste, and texture with the first two principal components.

The SensoMineR package from the statistics software R, version 2.15.0 (2011), was used to analyze the results according to Husson and Lê (2006). 


\subsection{OPTIMIZATION BY RESPONSE SURFACE METHODOLOGY}

The results shown in Table 3 indicate that the estimates of the linear parameters (potassium sorbate and citric acid) and the interactions between citric acid with pulp/sugar and potassium sorbate with pulp/sugar significantly influenced $(p<0.05)$ sample acceptability in relation to the attribute 'taste of guava'. These parameters provide substantial contributions to the development of the model.

Based on the results in Table 3, a surface analysis was performed as illustrated in Figure 1, sections $(A)$ and $(B)$. Regarding other sensory attributes, the parameters with estimates that were not significant $(p \geq 0.05)$ were not critical to explain the response variable. However, these variables were kept in the model to prevent the reduction of the predictive power of the coefficient of determination.

TABLE 3 - ESTIMATED EFFECTS AND REGRESSION COEFFICIENTS FOR THE EVALUATION OF THE VARIABLES 'APPEARANCE', 'COLOR', 'GUAVA TASTE', 'SWEETNESS', 'TEXTURE' AND ‘ OVERALL IMPRESSION' OF THE CODED VARIABLES

\begin{tabular}{|c|c|c|c|c|}
\hline Sensory attributes & Factor & Effect & Regression coefficient & $P$ \\
\hline Appearance & $\begin{array}{c}\text { Mean } \\
\text { Acid } \\
\text { Sorbate } \\
\text { Pulp/Sugar } \\
\text { Acid *Sorbate } \\
\text { Acid *Pulp/Sugar } \\
\text { Sorbate *Pulp/Sugar }\end{array}$ & $\begin{array}{l}6.72 \\
0.28 \\
0.12 \\
-0.08 \\
0.24 \\
-0.18 \\
-0.10\end{array}$ & $\begin{array}{l}6.72 \\
0.14 \\
0.06 \\
-0.04 \\
0.12 \\
-0.09 \\
-0.05\end{array}$ & $\begin{array}{l}0.00 \\
0.15 \\
0.45 \\
0.60 \\
0.19 \\
0.31 \\
0.55\end{array}$ \\
\hline Color & $\begin{array}{c}\text { Mean } \\
\text { Acid } \\
\text { Sorbate } \\
\text { Pulp/Sugar } \\
\text { Acid }{ }^{*} \text { Sorbate } \\
\text { Acid }{ }^{*} \text { Pulp/Sugar } \\
\text { Sorbate }{ }^{*} \text { Pulp/Sugar }\end{array}$ & $\begin{array}{r}6.93 \\
-0.34 \\
0.14 \\
-0.12 \\
0.04 \\
0.10 \\
-0.24\end{array}$ & $\begin{array}{r}6.93 \\
-0.17 \\
0.07 \\
-0.06 \\
0.02 \\
0.05 \\
-0.12\end{array}$ & $\begin{array}{l}0.00 \\
0.08 \\
0.37 \\
0.43 \\
0.79 \\
0.55 \\
0.18\end{array}$ \\
\hline Taste of guava & $\begin{array}{c}\text { Mean } \\
\text { Acid } \\
\text { Sorbate } \\
\text { Pulp/Sugar } \\
\text { Acid }{ }^{*} \text { Sorbate } \\
\text { Acid }{ }^{*} \text { Pulp/Sugar } \\
\text { Sorbate*Pulp/Sugar }\end{array}$ & $\begin{array}{c}-6.79 \\
-0.18 \\
0.12 \\
0.04 \\
0.04 \\
0.12 \\
-0.20\end{array}$ & $\begin{array}{l}-1.79 \\
-0.09 \\
0.06 \\
0.02 \\
0.02 \\
0.06 \\
-0.10\end{array}$ & $\begin{array}{l}0.10 \\
0.00 \\
0.01 \\
0.17 \\
0.17 \\
0.17 \\
0.02\end{array}$ \\
\hline Sweetness & $\begin{array}{c}\text { Mean } \\
\text { Acid } \\
\text { Sorbate } \\
\text { Pulp/Sugar } \\
\text { Acid }{ }^{*} \text { Sorbate } \\
\text { Acid }{ }^{*} \text { Pulp/Sugar } \\
\text { Sorbate *Pulp/Sugar }\end{array}$ & $\begin{array}{l}-6.20 \\
-0.14 \\
0.20 \\
0.10 \\
0.16 \\
-0.20 \\
-0.24\end{array}$ & $\begin{array}{l}-0.10 \\
6.69 \\
-0.07 \\
0.10 \\
0.05 \\
0.08 \\
-0.10 \\
-0.12\end{array}$ & $\begin{array}{l}0.02 \\
0.00 \\
0.47 \\
0.33 \\
0.59 \\
0.41 \\
0.33 \\
0.25\end{array}$ \\
\hline Texture & $\begin{array}{c}\text { Mean } \\
\text { Acid } \\
\text { Sorbate } \\
\text { Pulp/Sugar } \\
\text { Acid }{ }^{*} \text { Sorbate } \\
\text { Acid }{ }^{*} \text { Pulp/Sugar } \\
\text { Sorbate *Pulp/Sugar }\end{array}$ & $\begin{array}{l}6.56 \\
0.58 \\
0.06 \\
-0.24 \\
0.32 \\
-0.50 \\
-0.18\end{array}$ & $\begin{array}{l}6.56 \\
0.29 \\
0.03 \\
-0.12 \\
0.16 \\
-0.25 \\
-0.09\end{array}$ & $\begin{array}{l}0.00 \\
0.07 \\
0.81 \\
0.34 \\
0.23 \\
0.10 \\
0.48\end{array}$ \\
\hline Overall impression & $\begin{array}{c}\text { Mean } \\
\text { Acid } \\
\text { Sorbate } \\
\text { Pulp/Sugar } \\
\text { Acid *Sorbate } \\
\text { Acid *Pulp/Sugar } \\
\text { Sorbate *Pulp/Sugar }\end{array}$ & $\begin{array}{l}6.71 \\
0.10 \\
0.12 \\
-0.04 \\
0.20 \\
-0.30 \\
-0.10 \\
\end{array}$ & $\begin{array}{l}6.00 \\
0.05 \\
0.06 \\
-0.02 \\
0.10 \\
-0.15 \\
-0.05 \\
\end{array}$ & $\begin{array}{l}0.00 \\
0.69 \\
0.65 \\
0.86 \\
0.45 \\
0.26 \\
0.72 \\
\end{array}$ \\
\hline
\end{tabular}


Based on the results in Table 3, a surface analysis was performed as illustrated in Figure 1, sections $(A)$ and $(B)$. Regarding other sensory attributes, the parameters with estimates that were not significant $(p \geq 0.05)$ were not critical to explain the response variable. However, these variables were kept in the model to prevent the reduction of the predictive power of the coefficient of determination.
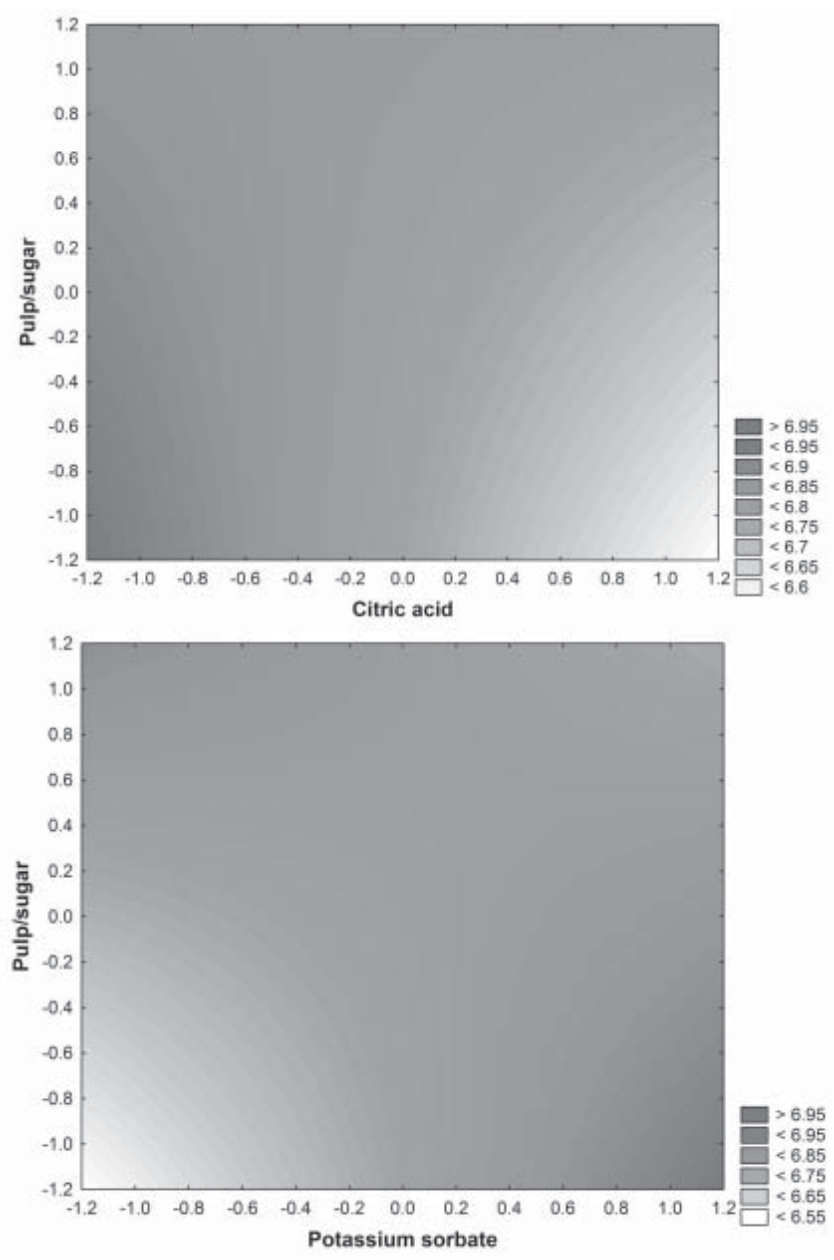

\section{FIGURE 1 - CONTOUR SURFACE FOR THE VARIABLE 'TASTE OF GUAVA'. VARIABLES THAT DO NOT APPEAR IN THE GRAPHS ARE FIXED AT THE CENTER POINT}

The negative linear effect of citric acid on the dependent variable 'guava taste' indicated a reduction in this variable within the scope of this study, contributing to reduced acceptability based on guava taste. The opposite occurs with the variable 'potassium sorbate'. The acceptance of the samples based on 'guava taste' may be attributed to increased $\mathrm{pH}$ and decreased acidity among the treatments. The addition of potassium sorbate to food generally leads to an increase in $\mathrm{pH}$ by approximately 0.1 to $0.5 \mathrm{pH}$ units, depending on the quantity, $\mathrm{pH}$ and type of product (PADILLAZAKOUR \& ANDERSON, 1998).

The shape of the contour lines in Figure 1 indicates the possible existence of a stationary point outside the experimental region. Visual analysis alone could lead to an incorrect interpretation. Therefore, the application of another statistical methodology, such as the Ridge method, is required to find an optimal value closer to the limits of the experimental region. With this limitation, and the fact that the majority of the parameters in the response surface model were not significant (Table 3), another technique was used. A statistical technique known as preference map was used 
in an attempt to optimize the ideal conditions required to prepare sweet guava without ignoring the individual scores obtained for each consumer. Such results do not disqualify the response surface methodology in evaluating acceptance data. Other studies (MENDES et al., 2001; CASTRO et al., 2004; DESHPANDE, CHINNAN \& MCWATTERS, 2008) have shown that the application of this statistical method can help to optimize the processing and formulation of products through consumer testing.

\subsection{PREFERENCE MAP}

The position of the points in the quadrants as plotted on the preference map (Figure 2) shows that treatment 2 (without the addition of potassium sorbate and containing a higher concentration of sugar and citric acid) was preferred in relation to overall impression. Treatment 2 is positioned in an area where approximately $80 \%$ of the consumers gave the treatment an above average score, indicating that consumers preferred the sample with a higher concentration of sugar and acid. Royer et al. (2006) showed contrary results studying on optimization of the production of jelly from apple pomace and quince, being the judges appreciated the jelly with the highest quince content and the lowest sugar content.

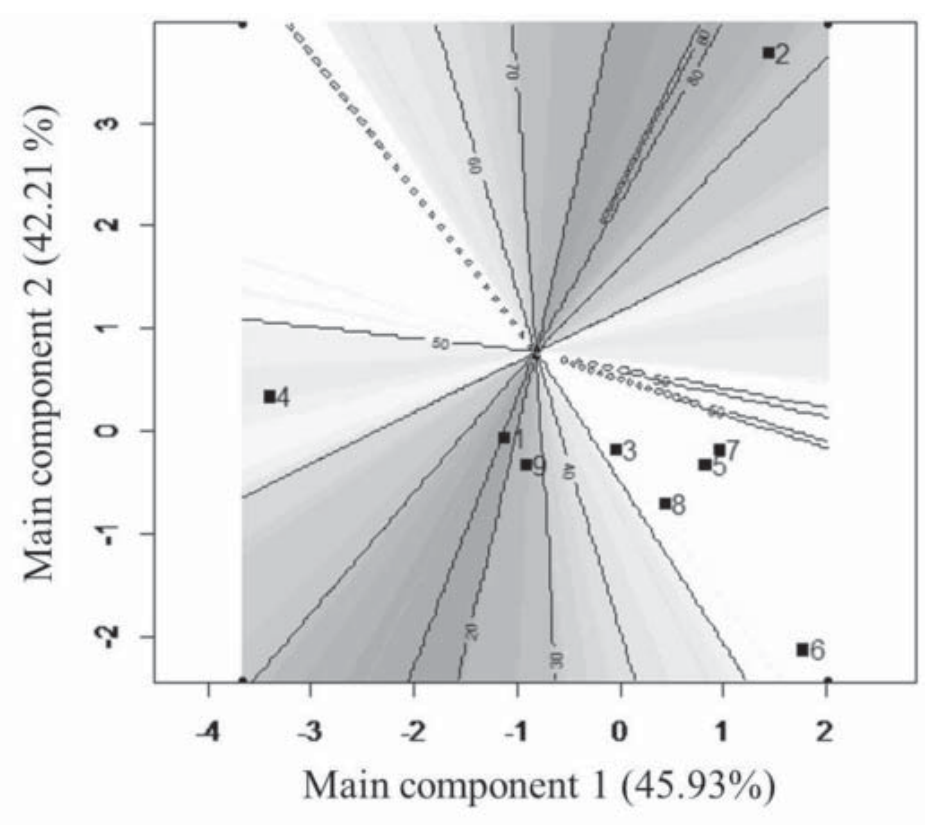

FIGURE 2 - PREFERENCE MAPPING FOR 9 TREATMENTS OF SWEET GUAVA

*Treatment 9: mean acceptance value for treatments 9, 10 and 11.

Prior to the construction of the preference map, the estimation of principal components (Figure 3 ) indicated that $87 \%$ of the total variation in acceptance data regarding the sensory attributes appearance, color, guava taste, sweetness and texture may be explained by the first two principal components. For this reason a two-dimensional graph was built.

The correlation circle (Figure 3) indicates that the acceptance of treatment 2 was mainly positively influenced by the sensory attributes 'sweetness', 'appearance' and 'texture'. This may also be verified in the mean acceptance scores table (Table 4). The table shows that the mean scores for sweetness, appearance and texture in treatment 2 ranged between 7 and 8 (corresponding to hedonic ratings 'I like moderately' and 'I like very much'), whereas the mean scores for the other treatments ranged between 6 and 7 (corresponding to hedonic ratings 'I like slightly' and 'I like moderately). 
TABLE 4 - MEAN ACCEPTANCE SCORES FOR SWEET GUAVA IN RELATION TO APPEARANCE, COLOR, SWEETNESS, GUAVA TASTE, AND TEXTURE

\begin{tabular}{lccccccccc}
\hline \multirow{2}{*}{ Sensory attributes } & \multicolumn{8}{c}{ Mean acceptance scores* attributed to the treatments } \\
& \multicolumn{1}{c}{ T1 } & T2 & T3 & T4 & T5 & T6 & T7 & T8 & T9 \\
\cline { 2 - 11 } & 6.77 & 7.39 & 6.73 & 6.66 & 6.66 & 6.43 & 6.64 & 6.68 & 6.45 \\
Appearance & 6.66 & 7.09 & 6.86 & 6.50 & 7.02 & 7.34 & 7.00 & 7.14 & 6.61 \\
Color & 6.43 & 7.07 & 6.61 & 6.16 & 6.91 & 6.55 & 6.82 & 6.57 & 6.73 \\
Sweetness & 6.75 & 6.82 & 6.82 & 6.43 & 6.80 & 7.05 & 6.91 & 6.80 & 6.73 \\
Guava taste & 6.41 & 7.50 & 6.36 & 6.77 & 6.16 & 5.93 & 6.45 & 6.18 & 6.48 \\
Texture & & & & & & & & & \\
\hline
\end{tabular}

* by 44 consumers.
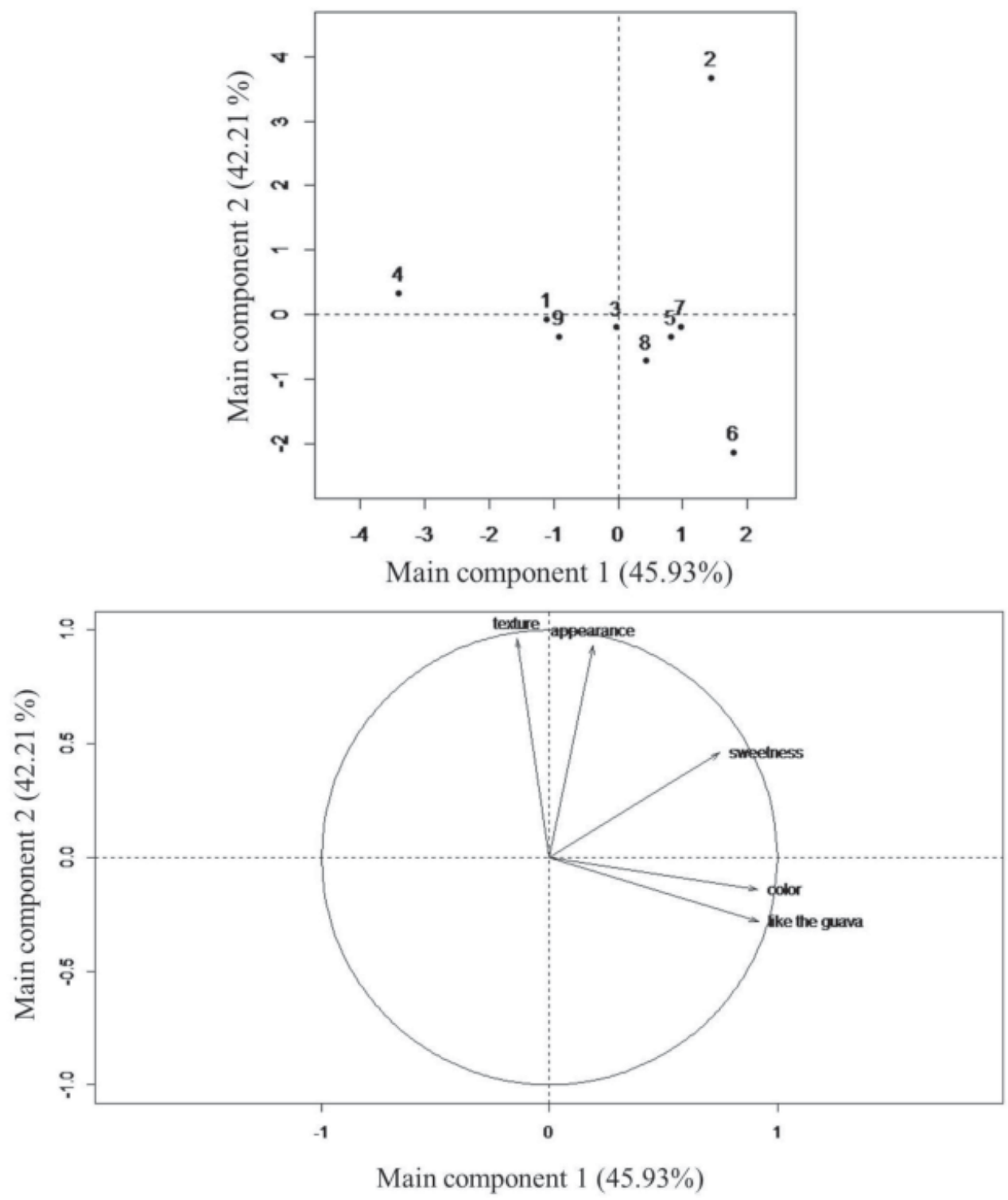

FIGURE 3 - PRINCIPAL COMPONENT ANALYSIS (A) AND CORRELATION CIRCLE (B) REGARDING ACCEPTANCE SCORES FOR NINE SWEET GUAVA TREATMENTS

\footnotetext{
* Treatment 9: mean acceptance value obtained for treatments 9, 10 and 11.
} 
The results reveal that, although treatment 2 was preferred by the consumers, the acceptance scores for the other treatments ranged between 6 ('I like slightly') and 7 ('I like moderately') in every attribute (Table 4).

Only the treatments with additional acid included in their formulations $(1,2,3,4,9,10$ and 11) presented a firm texture that is characteristic of sliceable sweet guava. The samples that did not have acid added to the formulation (5, 6, 7 and 8$)$ failed to reach a firm sliceable consistency, demonstrating the importance of adjusting the $\mathrm{pH}$ of the preserve to allow pectin to function in the formation of a gel. According to Evangeliou, Richardson \& Morris (2000) and Yukinori et al. (2004) the functionality of pectin is dependent on molecular size, degree of methoxylation, $\mathrm{pH}$ and ion force. Although it was not significant at $p \geq 0.05$, the regression coefficient attributed to the linear parameter for 'citric acid' proved positive (Table 3 ), and showed the influence of this factor in increased acceptability in relation to texture. The preference map (Figure 3) shows that the percentage of preference for treatment 2 $(80 \%)$ was much higher than the other 8 treatments (between $30 \%$ to $50 \%$ ).

\section{CONCLUSION}

In this study, response surface methodology alone proved to be insufficient to achieve an optimal formulation for the preparation of sweet guava. Based on the preference map and the correlation circle, it is possible to conclude that the best formulation is the one without the addition of potassium sorbate and containing a higher concentration of sugar and citric acid.

\section{RESUMO}

\section{OTIMIZAÇÃO DE DOCE DE GOIABA UTILIZANDO TESTE DE ACEITAÇÃO, METODOLOGIA DE SUPERFÍCIE DE RESPOSTA E MAPA DE PREFERÊNCIA}

Este estudo objetivou avaliar a influência das variáveis independentes concentração de ácido cítrico, concentração de sorbato de potássio e razão entre polpa/açúcar na aceitação de doce de goiaba. Os dados obtidos foram analisados pelas metodologias estatísticas de mapa de preferência e superfície de resposta para verificar a tendência da preferência dos consumidores pelo produto. A metodologia de superfície de resposta, por si só, não foi suficiente para encontrar a formulação ótima para a elaboração do doce de goiaba. Por meio da análise do mapa de preferência verificou-se maior aceitabilidade dos tratamentos com maior teor de açúcar e de ácido cítrico, sendo essa influenciada pelos parâmetros de doçura, aparência e textura dos doces.

PALAVRAS-CHAVE: ANÁLISE SENSORIAL; ÁCIDO CÍTRICO; SORBATO DE POTÁSSIO; AÇÚCAR; DOCE DE GOIABA.

\section{REFERENCES}

1 ABDULLAD, A.; CHENG, T.C. Optimization of reduced calorie tropical mixed fruits jam. Food Quality and Preference, V. 12 , n. 1, p. $63-68,2001$.

2 BARROS NETO, B.; SCARMINIO, I.S.; BRUNS, R.E. Planejamento e otimização de experimentos. Campinas: Unicamp, 1995.

3 BOX, G.E.P.; DRAPER, N.R. Response surfaces, mixtures, and ridge analyses. New York: John Wiley \& Sons, 2007. $857 \mathrm{p}$.

4 BRASIL, Ministério da Saúde. Agência Nacional de Vigilância Sanitária. Resolução normativa n. 9 de 1978. Diário Oficial [da] República Federativa do Brasil, Brasília, DF, 04 de maio de 1978.

5 BRITO, A.C.W.; DEMCZUK JUNIOR, B.; STERTZ, S.C.; FREITAS, R.J.S. de. Caracterização e estabilidade de purê misto de frutas, fonte de fibra alimentar. Boletim do CEPPA, v. 29, n. 1, p. 137-146, 2011.

6 BRITO, C.A.K.; SIQUEIRA, P.B.; DE SOUZA, J.C.; BOLINI, H.M.A. In vitro antioxidant capacity, phenolic, ascorbic acid and lycopene content of guava (psidium guajava I.) juices and nectars. Boletim do CEPPA, v. 27, n. 2, p. 175-182, 2009.

7 CARDELLO, H.M.A.B.; FARIA, J.B. Análise de aceitação de aguardente de cana por testes afetivos e mapa de preferência interno. Ciência e Tecnologia de Alimentos, v. 2, n. 1, p. 32-36, 2000. 
8 CASTRO, I.A.; TIRAPEGUI, J.L.; SILVA, R.S.S.F.; CUTRIM, A.J.S. Sensory evaluation of a milk formulation supplemented with $n^{3}$ polyunsaturated fatty acids and soluble fibres. Food Chemistry, v. 85, p. 503-512, 2004.

9 CHANG, Y.K.; SILVA, M.R.; GUTKOSKI, L.C.; SEBIO, L.; DA SILVA, M.A.A.P. Development of extruded snacks using jatobá (Hymenaea stigonocarpa Mart) flour and cassava starch blends. Journal Food Agriculture, v. 78, n. 1, p. 59-66, 1998.

10 DESHPANDE, R.P.; CHINNAN, M.S.; MCWATTERS, K.H. Optimization of a chocolate-flavored, peanut-soy beverage using response surface methodology (RSM) as applied to consumer acceptability data. LWT, v. 41, p. 1485-1492, 2008.

11 EVANGELIU, V.; RICHARDSON, R.K.; MORRIS, E.R. Effect of pH, sugar type and thermal annealing on high-methoxy pectin gels. Carbohydrate Polymers, v. 42, p. 245-259, 2000.

12 HOWARD, B.M.; HUNG, Y.; MCWATTERS, K. Analysis of ingredient functionality and formulation optimization of pasta supplemented with peanut flour. Journal of Food Science, v. 76, n. 1, p. E40-47, 2011.

13 HUSSON, F.; LE, S. SensormineR: a package for sensory data analysis with r. use r! Science Aliments, v. 26, n. 4, p. 355-356, 2006.

14 KUMAR, S.B.; RAVI, R.; SARASWATHI, G. Optimization of fruit punch using mixture design. Journal of Food Science, v. 75 , n. 1, p.S1-7, 2010

15 LEE, Y.S; YOUM, G.; OWENS, C.M.; MEULLENET, J.F. Optimization of consumer acceptability and sensory characteristics for marinated broiler breast meat. Journal of Food Science, v. 76, n. 8, p. S478 -84, 2011.

16 MATSUMO, H.; URITANE, I. Phisiological behaviour of peroxidase enzymes in sweet potato root tissue injured by cutting or back root. Plant and Cell Physiology, v. 13, n. 6, p. 1091-1101, 1972.

17 MENDES, L.C.; MENEZES, H.C.; APARECIDA, M.; DA SILVA, A.P. Optimization of the roasting of robusta coffee (C. canephora conillon) using acceptability tests and RSM. Food Quality and Preference, v.12, p. 153-162, 2001.

18 MORI, E.E.M.; YOTSUANAGI, K.; FERREIRA, V.L.F. Análise sensorial de goiabadas de marcas comerciais. Ciência e Tecnologia de Alimentos, v. 18, n. 1, p. 105-110, 1998.

19 MOSKOWITZ, H.R. Product optimization approaches and applications. In: MAcFIE, J.J.; THOMSON, D.M.H. Measurement of food preferences. Glasgow: Blackie Academic \& Professional, 1994. 301 p.

20 PADILIA-ZAKOUR, O.; ANDERSON, J.L. Chemical food preservatives: benzoate \& sorbate. New York: Venture, 1998.

21 R DEVELOPMENT CORE TEAN. R: a language and environment for statistical computing. Vienna: R Foundation for Statistical Computing, 2007.

22 REIS, R.C.; REGAZZI, A.J.; CARNEIRO, J.C.S.; MINIM, V.P.R. Mapa de preferência. In: MINIM, V.P.R. Análise sensorial: estudo com consumidores. 2. ed. Viçosa: UFV, 2010. 308 p.

23 ROYER, G.; MADIETA, E.; SYMONEAUX, R.; JOURJON, F. Preliminary study of the production of apple pomace and quince jelly. Food Science and Technology, v. 39, p. 1022-1025, 2006.

$24 \mathrm{SCHLICH}, \mathrm{P}$. Preference mapping: relating consumer preferences to sensory or instrumental measurements. Bioflavour, v. 48 , n. 75 , p. $135-150,1995$

25 STATSOFT Inc. Statistica (Data Analysis Software System). V. 8.0. Tusa, USA, 2008.

26 STONE, H.; SIDEL, J. Sensory evaluation practices. New York: Academic Press, 2004. 377 p.

27 TORREZAN, R. Iniciando um pequeno e grande negócio agroindustrial: frutas em calda, geléias e doces. Rio de Janeiro: Embrapa Agroindústria de Alimentos, 2003.

28 YUKINORI, S.; SHIMA, K.; YOSHINOBU, I.; OSATO, M. Effect of water activity and solvent-ordering on intermolecular interaction of high-methoxyl pectins in various sugar solutions. Food Hydrocolloids, v. 18, n. 4, p. 527-534, 2004.

29 WAKELING, I.N.; MAcFIE, J.H. Designing consumer trials balanced for first and higher orders of carry-over effect when only a subset of k samples from t may be tested. Food Quality and Preference, v. 6, n. 4, p. 299-308, 1995.

\section{ACKNOWLEDGEMENTS}

Financial support for this study was provided in part by the Conselho Nacional de Desenvolvimento Científico e Tecnológico (CNPq) Brazil and the Fundação de Amparo à Pesquisa de Minas Gerais (FAPEMIG) Brazil. 